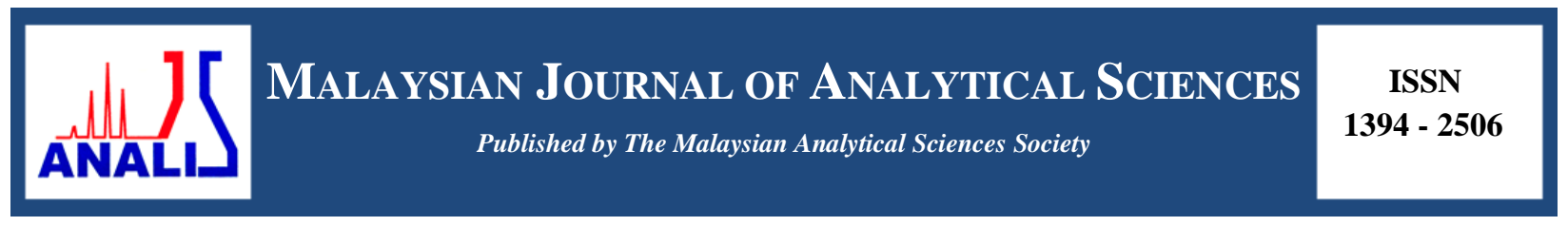

\title{
SOL-GEL/CHITOSAN HYBRID THIN FILM IMMOBILISED WITH CURCUMIN AS pH INDICATOR FOR pH SENSOR FABRICATION
}

\author{
(Filem Nipis Hibrid Sol-gel/Kitosan Terpegun dengan Kurkumin sebagai Penunjuk pH bagi \\ Fabrikasi Sensor $\mathrm{pH}$ )
}

\author{
Rosmawani Mohammad $^{1,2} *$ and Musa Ahmad ${ }^{2,3}$ \\ ${ }^{I}$ Faculty of Bioengineering and Technology, \\ Universiti Malaysia Kelantan, Jeli Campus, Locked Bag No. 100, 17600 Jeli, Kelantan, Malaysia \\ ${ }^{2}$ School of Chemical Sciences and Food Technology, Faculty of Sciences and Technology, \\ Universiti Kebangsaan Malaysia, 43600 UKM Bangi, Selangor, Malaysia \\ ${ }^{3}$ Industrial Chemical Technology Program, Faculty of Science and Technology, \\ Universiti Sains Islam Malaysia, Bandar Baru Nilai, 71800 Nilai, Negeri Sembilan, Malaysia \\ *Corresponding author: rosmawani@umk.edu.my
}

Received: 10 October 2018; Accepted: 21 February 2019

\begin{abstract}
An optical $\mathrm{pH}$ sensor based on the immobilisation of curcumin in sol-gel/chitosan hybrid thin films was fabricated on a cellulose acetate sheet as solid support for preparing a thin film. The thin film was prepared using the dip coating method. This sensor gave a range of linear $\mathrm{pH}$ responses at $\mathrm{pH} 9-13\left(\mathrm{R}^{2}=0.9821\right)$. The relative standard deviation $(\mathrm{RSD})$ values of repeatability of this sensor were $7.03 \%(\mathrm{pH} 10)$ and $3.34 \%(\mathrm{pH} 11)$, while the RSD values of reproducibility were $7.46 \%(\mathrm{pH} 10)$ and $8.66 \%(\mathrm{pH}$ 11). The photostability of immobilised curcumin gave an RSD value of $2.37 \%$ for a study period of 15 weeks. This sensor had a response time between 10-20 s, and no hysteresis effect was observed when the $\mathrm{pH}$ in a cycle of $\mathrm{pH} 2-12-2$ was measured. This sensor was applied in the determination of $\mathrm{pH}$ in real samples, and the results were comparable to a conventional $\mathrm{pH}$ meter.
\end{abstract}

Keywords: optical pH sensor, hybrid sol-gel/chitosan, curcumin, thin film

Abstrak

Sensor optik pH berdasarkan pemegunan kurkumin dalam filem nipis hibrid sol-gel / kitosan difabrikasi di atas kepingan selulosa asetat sebagai penyokong untuk penyediaan filem nipis. Filem nipis telah disediakan menggunakan kaedah penyalutan celup. Sensor ini memberikan julat rangsangan linear $\mathrm{pH}$ pada $\mathrm{pH} 9-13\left(\mathrm{R}^{2}=0.9821\right)$. Nilai sisihan piawai relatif (RSD) bagi kebolehasilan sensor ini adalah 7.03\% ( $\mathrm{pH} 10)$ dan 3.34\% ( $\mathrm{pH} 11)$, manakala nilai RSD kebolehulangan ialah 7.46\% (pH 10) dan $8.66 \%$ (pH 11). Kestabilanfoto reagen kurkumin terpegun memberikan nilai RSD 2.37\% untuk tempoh kajian selama 15 minggu. Sensor ini mempunyai masa tindak balas antara 10-20 s dan tiada kesan histerisis diperhatikan apabila sensor digunakan untuk mengukur $\mathrm{pH}$ dalam kitaran $\mathrm{pH}$ 2-12-2. Sensor ini digunakan untuk penentuan $\mathrm{pH}$ dalam sampel sebenar dan hasilnya dapat dibandingkan dengan meter $\mathrm{pH}$ konvensional.

Kata kunci: sensor pH optik, sol-gel hibrid / kitosan, kurkumin, filem nipis

\section{Introduction}

Various synthetic reagents have been utilised as $\mathrm{pH}$ indicators. However, there are not many indicators in the $\mathrm{pH}$ range of 10-14 [1]. In this study, curcumin was chosen as a $\mathrm{pH}$ indicator and given a linear response at $\mathrm{pH}$ 8-12. Curcumin [1,7-bis (4-hydroxy-3-methoxyphenyl)-1,6-heptadiene-3,5-dione] is a natural yellow dye obtainable from 


\section{Rosmawani \& Musa: SOL-GEL/CHITOSAN HYBRID THIN FILM IMMOBILISED WITH CURCUMIN AS pH INDICATOR FOR pH SENSOR FABRICATION}

\section{Curcuma longa (turmeric).}

For the past decade, sol-gel has been used in various fields of chemical sensors and biosensors. This is due to its uniqueness due to several of its qualities such as chemical inertness, biodegradable, high photochemical, thermal stability and it does not swell in aqueous and organic solution [2]. However, the major disadvantage of sol-gel is the cracking problem. A considerable number of studies have been conducted to overcome the cracking problem by forming hybrid matrices including poly(ethylene oxide)-silica hybrid nanocomposites [3], silica-titania hybrid nanoparticles [4], silica matrix-poly(aniline boronic acid) hybrid [5], hybrid chitosan (CS)/calcium aluminosilicate nanocomposites thin films and membranes [6].

Meanwhile, chitosan has also been widely used in membrane application because it is chemically resistant, has good film-forming and hydrophilicity. However, the chitosan membrane tends to swell easily in water and alcohol solutions. Therefore, various research have been conducted to overcome this problem such as investigating the cross-linked structure of chitosan and hybridised chitosan with other polymers and inorganic substances [7].

In this work, the sol-gel/chitosan (SC) hybrid thin films were developed for the fabrication of an optical $\mathrm{pH}$ sensor. Hybridisation was used to overcome the weaknesses in both the sol-gel and chitosan as stated above. The hybridisation of sol-gel with chitosan is stabilised by strong hydrogen bonding, and the hybridization was able to overcome the brittleness of the sol-gel matrix $[2,8,9]$. The curcumin reagent was chosen as the $\mathrm{pH}$ indicator to be immobilised into the SC hybrid film in this work. In our previous work, sol-gel has been hybridised with chitosan melamine with different ratios [10]. To date, no study of curcumin reagent immobilised in sol-gel/pure chitosan hybrid thin film for optical $\mathrm{pH}$ sensor development has been reported.

\section{Reagents}

\section{Materials and Methods}

The curcumin $(65-70 \%)$ was purchased from Sigma (St. Louis, MO, USA). Hydrochloric acid (37\%) was obtained from Scharlau (Adelaide, Australia) and ethanol (95\%) from Systerm (Shah Alam, Selangor, Malaysia). Tetraethyl orthosilicate (TEOS), Triton-x 100 and tris(hydroxymethyl)aminomethane were purchased from Fluka (Buchs, Switzerland). Sodium hydroxide and potassium chloride were acquired from Merck (Darmstadt, Germany). Potassium dihydrogen phosphate was purchased from Bendosen (Johor, Malaysia) and sodium hydrogen carbonate from BDH (London). Chitosan was supplied by Molbase (Shanghai, China).

\section{Preparation of the stock solutions}

The stock solutions of the sol-gel and chitosan were prepared according to the methods mentioned in our previous work [11], with some modifications. The SC hybrid solution was prepared by mixing the sol-gel solution and chitosan solution at a volume ratio of 9:1 (v/v) respectively. The mixture was stirred with a magnetic stirrer at 200 $\mathrm{rpm}$ for 2 hours in a sample bottle and prepared freshly for every fabrication of the optical thin film.

For immobilisation, the saturated curcumin reagent was prepared by dissolving this reagent in ethanol (95\%) and stirred using a magnetic stirrer at $200 \mathrm{rpm}$ for 1 hour. Then, this solution was left for a few hours until the undissolved reagent precipitated.

\section{Construction of optical pH sensor}

Initially, the mixture of the SC hybrid solution $(9: 1, \mathrm{v} / \mathrm{v})$ and saturated curcumin reagent was prepared at a volume ratio of 2:1. This solution was stirred for 10-15 minutes using a magnetic stirrer bar. A thin film was prepared using the dip coating method, and cellulose acetate sheets were used as solid support with a measurement of $7.3 \mathrm{~cm} \times 0.9$ $\mathrm{cm}$. The cellulose acetate sheets were dipped into the mixture of SC-curcumin using a dip coater. The cellulose acetate sheets containing hybrid SC-curcumin reagent were kept in a desiccator at room temperature overnight for drying purposes.

\section{Evaluation of the optical $\mathrm{pH}$ sensor response}

The absorbance readings were measured using an ultraviolet-visible spectrophotometer (model Varian Cary 50). Before use, the film was immersed in water to allow for the excess and unbound dyes to be removed. Then, the film 
was immersed in buffer solutions of $\mathrm{pH} 1-13$, and the absorbance spectra were measured at a wavelength of 300 $700 \mathrm{~nm}$. The response of the optical $\mathrm{pH}$ sensor was studied at a fixed wavelength of $502 \mathrm{~nm}$ as determined from the spectra.

\section{Results and Discussion}

The characterisation of the immobilised curcumin reagent was conducted for the development of an optical $\mathrm{pH}$ sensor including the optimisation of the volume ratio of the SC, $\mathrm{pH}$ effect, repeatability, reproducibility, hysteresis effect, stability, and real sample analysis. However, response time was not taken into consideration because of the difficulty in measuring the absorbance. This is because when the film was immersed in the buffer solutions pH 1-13, the colour changes that occurred were very fast (within 10-15 seconds). This was caused by the quick diffusion of $\mathrm{H}^{+}$ions through silica sol-gel hosts [12].

\section{The effect of the SC ratio on the optical $\mathrm{pH}$ sensor response}

The optimisation of the volume ratio of sol-gel and chitosan used was studied to get the optimum ratio that could overcome the cracking of the sol-gel film. As stated by Cajlakovic et al. [13], the addition of organic functional groups or organo-silane coupling agents containing epoxy, methacryl or amino functional groups can increase the gel's flexibility as well as reduce shrinkage, porosity, and density of the material. The volume ratios of sol-gel to chitosan studied were 9:1, 8:2, 7:3,6:4, and 5:5, and the pure sol-gel film was also scrutinised as a control. Our observation showed that the films became opaque with the increasing volume of chitosan in the hybrid solution. The film at a ratio of sol-gel: chitosan 9:1 became transparent, while the films at other ratios became cloudy and opaque. A similar observation has been reported in our previous study when chitosan melamine was used in fabricating the hybrid thin film. However, only $1 \%$ of chitosan melamine was suitable to be added to the sol-gel solution due to the higher content of amino groups in chitosan melamine [10]. Meanwhile, in this study, almost $10 \%$ of chitosan was found to be optimum to be added in the sol-gel solution in order to fabricate the hybrid thin film.

As reported by Nivens et al. [14], 3-aminopropyltriethoxysilane (APTES), which is a compound that has an amino group as chitosan, was incorporated into the sol-gel. They stated that the concentrations of APTES and water must be quite low in preparing acid-catalysed multicomponent sol-gels; otherwise, the gels will form two layers and become cloudy due to the protonation of the amino groups. Furthermore, they stated that APTES is one of the organo-silane coupling agents that is commonly used for sensors and is used to bond organic probe molecules to glass and silica sol-gel surfaces. It is essential to overcome the leaching problems of the indicator molecules when they are immobilised into the sol-gel without covalent bonding.

As a comparison between the hybrid SC 9:1 film and pure sol-gel film, the absorbance spectra of the immobilised curcumin reagent in the hybrid film are higher than those found in the pure sol-gel film as shown in Figure 1. Therefore, the SC hybrid film at the ratio of 9:1 is chosen for further studies as an optimum ratio because it could give higher absorbance and could overcome the cracking problems of the sol-gel film, besides obtaining a transparent film. As reported by Gang et al. [8], Miao and Tan [2], and Wei and Collinson [9], the SC hybrids are able to overcome the cracking problems of the sol-gel films.

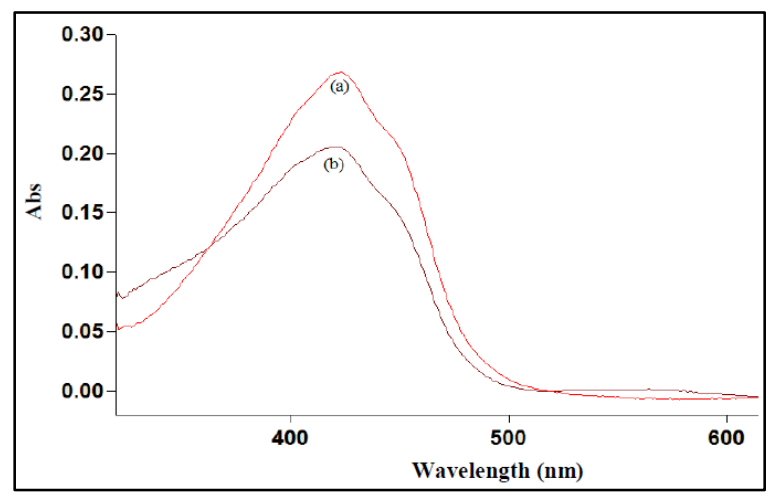

Figure 1. Absorbance spectra of curcumin immobilised in a) SC hybrid film at a ratio of 9:1 and b) sol-gel film 


\section{Analytical performance of the optical pH sensor}

The spectral characteristics of the immobilised curcumin in $\mathrm{pH} \mathrm{1-13} \mathrm{are} \mathrm{shown} \mathrm{in} \mathrm{Figure} \mathrm{2.} \mathrm{The} \mathrm{initial} \mathrm{colour} \mathrm{of} \mathrm{the}$ film containing the immobilised curcumin was yellow. When the film was immersed in a buffer of $\mathrm{pH} 1-13$, the film became yellow in the acidic and reddish-brown in the basic solutions. Figure 3 shows the graph of absorbance versus $\mathrm{pH}$ at the wavelengths of $423 \mathrm{~nm}$ and $502 \mathrm{~nm}$, which are representative of the protonation and deprotonation regions, respectively. The sigmoid shape of the response curve is observed in Figure 3 . The range of $\mathrm{pH}$ linear response for the curcumin reagent in the immobilised form is at $\mathrm{pH} 9-13\left(\mathrm{R}^{2}=0.9821\right)$, while the range of $\mathrm{pH}$ linear response for the curcumin reagent in the solution is at $\mathrm{pH} 8-12\left(\mathrm{R}^{2}=0.9854\right)$ [15]. Duong et al. [16] also reported the differences for the linear $\mathrm{pH}$ range in solution $(\mathrm{pH} \mathrm{5-7)}$ and the immobilised form ( $\mathrm{pH}$ 6-9) for developing an optical $\mathrm{pH}$ sensor based on fluoresceinamine isomer II, covalently immobilised in a sol-gel matrix. Several differences had been reported by other researchers when the reagent is in a different form (in solution and immobilised forms) such as the differences in $\mathrm{pKa}$ values [12,17,18], absorbance spectra [17, 19], wavelengths [12, 19-21], and range of $\mathrm{pH}$ linear responses [16, 20]. As stated by Kessler and Wolfbeis [22], the dye may undergo a few changes such as spectral shifts, fluorescence quantum yield differences and molar absorptivity due to the interaction between the dye and its microenvironment [23].

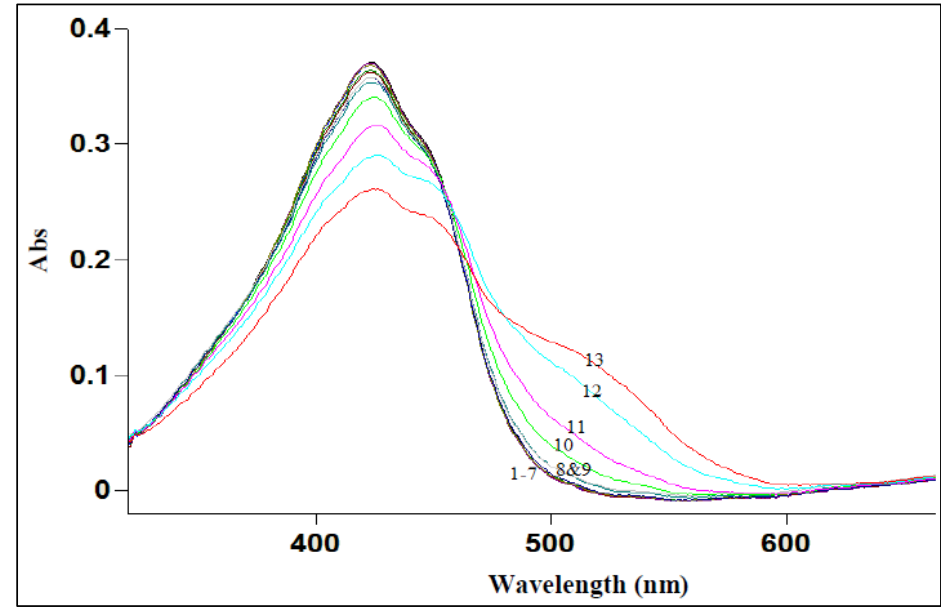

Figure 2. Absorbance spectra of curcumin immobilised in SC hybrid film (9:1) for pH 1-13

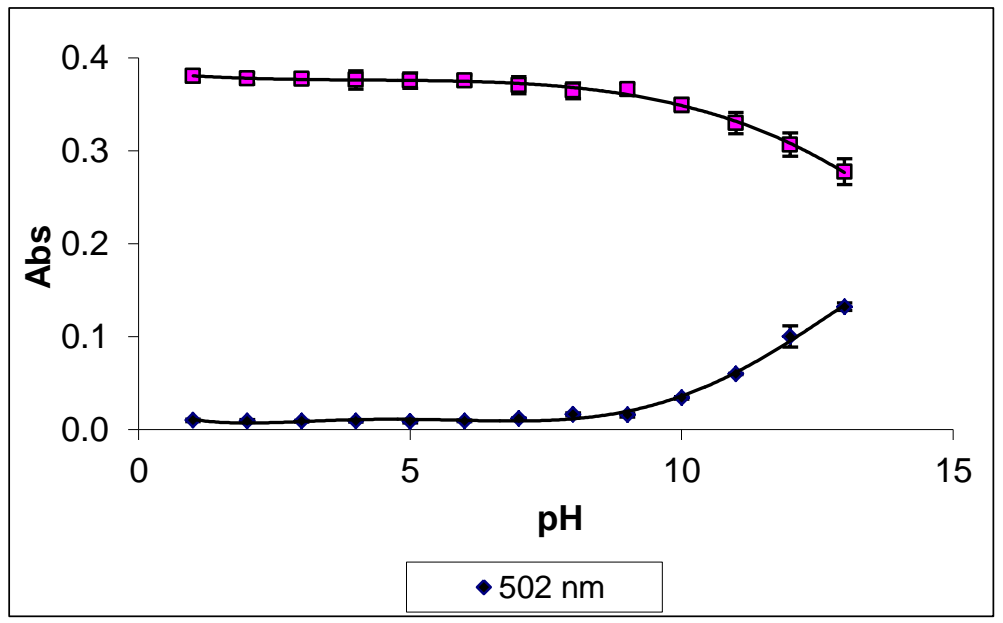

Figure 3. $\mathrm{pH}$ effect study of optical $\mathrm{pH}$ sensor towards $\mathrm{pH}$ 1-13 
The reproducibility and repeatability of the SC hybrid film immobilised with curcumin reagent were conducted in $\mathrm{pH} 10$ and $\mathrm{pH} 11$. The RSD of the repeatability is found to be $7.03 \%(\mathrm{pH} 10)$ and $3.34 \%(\mathrm{pH} 11)$, while for reproducibility, the RSD values are $7.46 \%(\mathrm{pH} 10)$ and $8.66 \%(\mathrm{pH} \mathrm{11)}$ for the seven measurements taken. As expected, the repeatability of the hybrid film is better than its reproducibility since the variation in the absorbance is considerably greater for reproducibility compared to repeatability. The same observation has been reported in the literature $[24,25]$. Therefore, a variation in absorbance was expected when measurements were taken at different points on different films. Meanwhile, the lower RSD obtained for repeatability was caused by using the same film and hence, the measurement could be taken at the same point on the same film. As a result, this could reduce the variation in absorbance when the absorbance reading was taken.

The reversibility of this optical sensor was studied by immersing the sensor in a buffer solution of $\mathrm{pH}$ 2-12 followed by a solution of $\mathrm{pH} \mathrm{12-2.} \mathrm{As} \mathrm{shown} \mathrm{in} \mathrm{Figure} \mathrm{4,} \mathrm{the} \mathrm{response} \mathrm{of} \mathrm{the} \mathrm{pH}$ sensor displays no hysteresis when the sensor is used to measure different $\mathrm{pH}$ in the cycle of $\mathrm{pH} 2-12-2$ (acid-base-acid). The t-test (confidence limit at 99\%) shows no significant differences, and these results confirm the reversibility of the $\mathrm{pH}$ sensor.

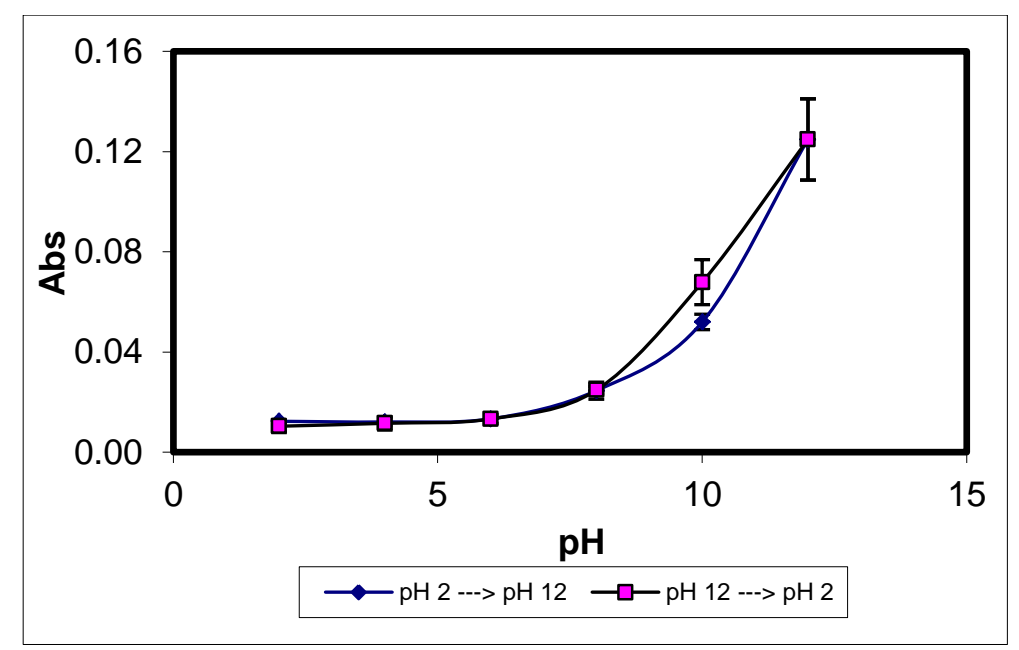

Figure 4. Hysteresis effect study on the response of the optical $\mathrm{pH}$ sensor

The absorbance reading $(423 \mathrm{~nm})$ on the first day is considered as $100 \%$ relative response. The SC hybrid film immobilised with curcumin reagent displays good storage stability for 15 weeks by maintaining $>93 \%$ of the original response when stored dry at room temperature (Figure 5). However, it decreases up to $28 \%$ from the original response at week-20. Therefore, this indicates that the SC hybrid film immobilised with curcumin reagent is stable for a period of 15 weeks. Similar trend has been reported in our previous work based on curcumin reagent immobilized in sol-gel/chitosan melamine hybrid matrices [10]. 


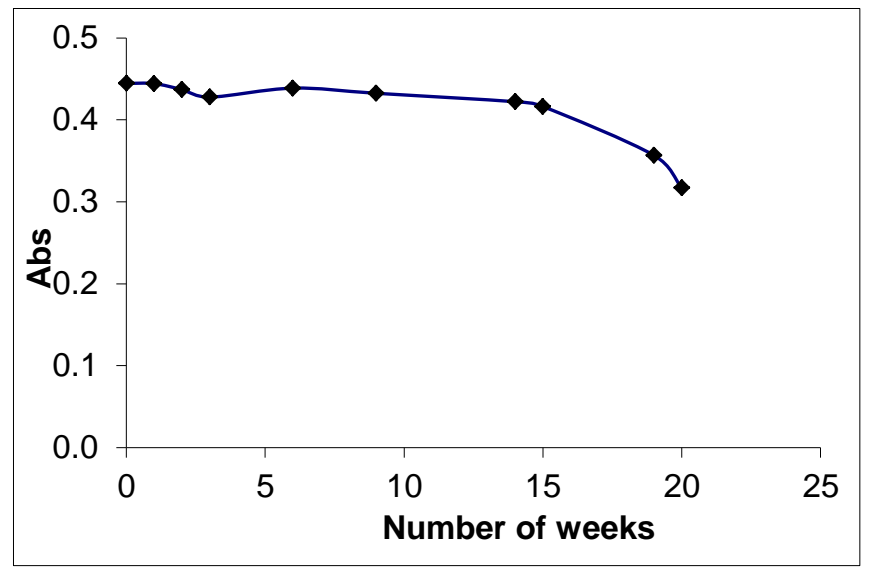

Figure 5. The shelf life of the SC hybrid film immobilised with curcumin reagent

\section{Real sample study}

This study was carried out using two samples, i.e., toothpaste and noodles. $6 \mathrm{~g}$ of toothpaste was dissolved in $60 \mathrm{~mL}$ of deionised water and filtered using filter paper. The filtrate was taken to measure the $\mathrm{pH}$ value using a $\mathrm{pH}$ meter. Meanwhile, the measurement of $\mathrm{pH}$ value based on $\mathrm{pH}$ sensor was carried out by immersing the hybrid film in the filtrate. Then, the absorbance readings of the hybrid film were measured using an ultraviolet-visible spectrophotometer at a wavelength of $502 \mathrm{~nm}$. For the noodle samples, $140 \mathrm{~g}$ of noodles were put in $150 \mathrm{~mL}$ of deionised water and the same procedures were carried out for the determination of $\mathrm{pH}$ values using $\mathrm{pH}$ meter and $\mathrm{pH}$ sensor. The determination of $\mathrm{pH}$ values for both samples using this optical $\mathrm{pH}$ sensor show no significant differences (confidence limit $=99 \%$ ) when compared with the results obtained by using a conventional $\mathrm{pH}$ meter (Tables 1 and 2).

Table 1. Determination of $\mathrm{pH}$ value for toothpaste using $\mathrm{pH}$ meter and $\mathrm{pH}$ sensor

\begin{tabular}{lccc}
\hline Measurement & $\mathbf{y}=\mathbf{a b s o r b a n c e}$ & $\mathbf{x}=\mathbf{p H}$ sensor & $\mathbf{p H}$ meter \\
\hline 1 & 0.0154 & 9.23 & 9.16 \\
2 & 0.0128 & 9.15 & 9.15 \\
3 & 0.0078 & 8.98 & 9.13 \\
4 & 0.0083 & 9.00 & 9.14 \\
\hline average & & 9.09 & 9.15 \\
standard deviations & & 0.1218 & 0.0129 \\
\hline
\end{tabular}

Table 2. Determination of $\mathrm{pH}$ value for noodles using $\mathrm{pH}$ meter and $\mathrm{pH}$ sensor

\begin{tabular}{lccc}
\hline Measurement & $\mathbf{y}$ =absorbance & $\mathbf{x}=\mathbf{p H}$ sensor & pH meter \\
\hline 1 & 0.0786 & 11.35 & 11.27 \\
2 & 0.0831 & 11.50 & 11.27 \\
3 & 0.0717 & 11.12 & 11.12 \\
4 & 0.0840 & 11.53 & 11.28 \\
\hline average & & 11.37 & 11.24 \\
standard deviations & & 0.1879 & 0.0768 \\
\hline
\end{tabular}




\section{Conclusion}

An optical pH sensor based on curcumin reagent immobilised in SC hybrid film was successfully developed. The incorporation of chitosan into the sol-gel can overcome the cracking problem of the sol-gel film and reduces the porosity of the sol-gel film, thus reducing the leaching problem of the sol-gel film. This optical $\mathrm{pH}$ sensor demonstrated good repeatability and reproducibility with no hysteresis effect observed in the cycle of $\mathrm{pH} 2-12-2$. In short, the advantageous features of this sensor include the ability to determine the wide range of alkaline medium and at high $\mathrm{pH}$ values since the range of $\mathrm{pH}$ linear response is from $\mathrm{pH} 9$ to $\mathrm{pH} 13$.

\section{Acknowledgements}

The authors are grateful for the facilities provided in the School of Chemical Sciences and Food Technology, Faculty of Sciences \& Technology, Universiti Kebangsaan Malaysia and the financial support under IRPA Topdown 09-03-03-0006.

\section{References}

1. Nourmohammadian, F., Davoodzadeh, M. and Abdol-Ali, A. (2007). New cyclopentadiene derivatives as novel pH indicators. Dyes and Pigments, 74: 741 - 743.

2. Miao, Y. and Tan, S. N. (2001). Amperometric hydrogen peroxide biosensor with silica sol-gel/chitosan film as immobilization matrix. Analytica Chimica Acta, 437(1): 87 - 93.

3. Fabbri, P., Pilati, F., Rovati, L., Kenzie, R. and Mijovic, J. (2011). Poly(ethylene oxide)-silica hybrids entrapping sensitive dyes for biomedical optical $\mathrm{pH}$ sensors: Molecular dynamics and optical response. Optical Materials 33(8): $1362-1369$.

4. Islam, S., Bidin, N., Riaz, S., Naseem, S. and Marsin, F. M. (2016). Correlation between structural and optical properties of surfactant assisted sol-gel based mesoporous $\mathrm{SiO}_{2}-\mathrm{TiO}_{2}$ hybrid nanoparticles for $\mathrm{pH}$ sensing/optochemical sensor. Sensors and Actuators B, 225: 66 - 73.

5. Li, J., Zhang, N., Sun, Q., Bai, Z. and Zheng, J. (2016). Electrochemical sensor for dopamine based on imprinted silica matrix-poly(aniline boronic acid) hybrid as recognition element. Talanta, 159: 379-386.

6. Elnahrawy, A. M., Kim, Y. S. and Ali, A. I. (2016). Synthesis of hybrid chitosan/calcium aluminosilicate using a sol-gel method for optical applications. Journal of Alloys and Compounds, 676: 432 - 439.

7. Ying-Ling, L., Yu-Huei, S., Kuir-Rain, L. and Juin-Yih, L. (2005). Crosslinked organic-inorganic hybrid chitosan membranes for pervaporation dehydration of isopropanol-water mixtures with a long-term stability. Journal of Membrane Science, 251: 233 - 238.

8. Gang, W., Jing-Juan, X., Hong-Yuan, C. and Zu-Hong, L. (2003). Amperometric hydrogen peroxide biosensor with sol-gel/chitosan network-like film as immobilization matrix. Biosensors and Bioelectrics, 18(4): 335 343.

9. Wei, H. and Collinson, M. M. (1995). Functional-group effects on the ion-exchange properties of organically modified silicates. Analytica Chimica Acta, 397: 113-121.

10. Mohammad, R., Ahmad, M. and Jamaluddin, M. D. (2009). Pembangunan sensor optik pH berasaskan reagen kurkumin terpegun dalam matriks hibrid sol-gel/kitosan melamin. Sains Malaysiana, 38(3): 413-418.

11. Mohammad, R., Ahmad, M. and Heng, L. Y. (2014). Chilli hotness determination based on optical capsaicin biosensor using stacked immobilisation technique. Sensors and Actuators B, 190: 593 - 600.

12. Villegas, M. A. and Pascual, L. (1999). Sol-gel silica coatings doped with a pH-sensitive chromophore. Thin Solid Film, 351: 103 - 108.

13. Cajlakovic, M., Lobnik, A. and Werner, T. (2002). Stability of new optical pH sensing material based on crosslinked poly (vinyl alcohol) copolymer. Analytical Chimica Acta, 455: 207 - 213.

14. Nivens, D. A., Zhang, Y. and Angel, S. M. (1998). A fiber-optic pH sensor prepared using a base-catalyzed organo-silica sol-gel. Analytical Chimica Acta, 376: 235-245.

15. Mohammad, R., Ahmad, M. and Jamaluddin, M. D. (2007). Potensi kurkumin sebagai penunjuk pH semulajadi untuk pembangunan sensor optik pH. Malaysian Journal of Analytical Sciences, 11(2): 351-360.

16. Duong, H. D., Ok-Jae, S., Lam, H. T. and Rhee, J. I. (2006). An optical pH sensor with extended detection range based on fluoresceinamine covalently bound to sol-gel support. Microchemical Journal, 84(1-2): 50-55.

17. Lin, J. and Liu, D. (2000). An optical pH sensor with a linear response over a broad range. Analytical Chimica 
Acta, 408: 49-55.

18. Malins, C., Glever, H. G., Keyes, T. E., Vos, J. G., Dressick, W. J. and MacCraith, B. D. (2000). Sol-gel immobilised ruthenium(II) polypyridyl complexes as chemical trandusers for optical $\mathrm{pH}$ sensing. Sensors and Actuators B, 67: $89-95$.

19. Ensafi, A. A. and Kazemzadeh, A. (1999). Optical pH sensor based on chemical modification of polymer film. Microchemical Journal, 63: 381 - 388.

20. Liu, Z., Luo, F. and Chen, T. (2004). Polymeric pH indicators immobilized PVA membranes for optical sensors of high basicity based on a kinetic process. Analytica Chimica Acta, 519: 147-153.

21. Safavi, A. and Abdollahi, H. (1998). Optical sensor for high pH values. Analytica Chimica Acta, 367: 167 173.

22. Kessler, M. A. and Wolfbeis, O. S. (1991). New highly fluorescent ketocyanine polarity probes. Spectrochim. Acta, Part A, 47(2):187 - 192.

23. Ertekin, K., Karapire, C., Alp, S., Yenigul, B. and Icli, S. (2003). Photophysical and photochemical characteristics of an azlactone dye in sol-gel matrix; a new fluorescent $\mathrm{pH}$ indicator. Dyes and Pigments, 56: $125-133$.

24. Ahmad, M. and Narayanaswamy, R. (1995). Development of an optical fibre Al(III) sensor based on immobilised chrome azurol S. Talanta, 42: 1337-1344.

25. Ahmad, M., Norezuny, M. and Jariah, A. (2001). Sensing material for oxygen gas prepared by doping sol-gel film with tris (2,2-bipyridyl) dichlororuthenium complex. Journal of Non-Crystalline Solids, 290: 86 - 91. 